\title{
Pharmaceutical Care in Primary Care: an Experience with Hypertensive Patients in the North of Brazil
}

\author{
Ilvia Silva Gomes, ${ }^{1}$ Elaine Menezes Rossi, ${ }^{\circledR}$ Samara Jamile Mendes, ${ }^{3 \oplus}$ Brigitte Rieckmann Martins dos Santos, ${ }^{4,5}$ \\ Wilson Sabino ${ }^{1}$ \\ Universidade Federal do Oeste do Pará,' Santarém, PA - Brazil \\ Universidade Federal de Mato Grosso - Campus Rondonópolis, ${ }^{2}$ Rondonópolis, MT - Brazil \\ Universidade de São Paulo, ${ }^{3}$ São Paulo, SP - Brazil \\ Universidade Municipal de São Caetano do Sul, ${ }^{4}$ São Caetano do Sul, SP - Brazil \\ Universidade Santa Cecília, Santos, SP - Brazil
}

\section{Abstract}

Background: Uncontrolled blood pressure has been associated with poor adherence to drug treatment.

Objective: To assess blood pressure control in hypertensive patients attending primary health centers after implementation of a pharmaceutical follow-up program in a city of the north of Brazil.

Methods: Observational, cross sectional, descriptive study with 163 hypertensive patients attending public primary health care centers - one located on the riverside and one in the urban area of the city of Santarem, western Pará, Brazil. Adherence to the anti-hypertensive treatment was assessed using the eight-item Morisky test. Pharmacotherapy follow-up (Dader method) of patients with uncontrolled hypertension and non-adherent to antihypertensive treatment was performed. Results of the normality test showed that the data did not follow a normal distribution. Continuous variables were then compared using the Wilcoxon signed-rank test, and categorical variables by the likelihood ratio and the McNemar tests. Statistical significance was set at 5\%.

Results: Of the total sample, $94.5 \%$ were not adherent to anti-hypertensive drug therapy and $77.2 \%$ had uncontrolled hypertension. Adherence rate was higher in men than women ( $p=0.006)$. Pharmacotherapy follow-up improved blood pressure levels, particularly systolic blood pressure $(\mathrm{p}<0.001)$.

Conclusion: An individualized pharmacotherapeutic follow-up, considering regional and cultural specificities, can contribute to the treatment of hypertensin in the primary care.

Keywords: Hypertension; Risk Factors; Patient Care Management; Medication Adherence; Epidemiology; Urban Area; Morbidity and Mortality.

\section{Introduction}

According to the National Survey on Access, Use and Promotion of Rational Use of Medicines (PNAUM, Pesquisa Nacional sobre Acesso, Utilização e Promoção do Uso Racional de Medicamentos), ${ }^{1}$ conducted in urban areas of the five geographical regions of Brazil, the prevalence of self-reported hypertension in the country is $23.7 \%$ (95\% confidence interval, CI, 22.8-24.6), with a greater predominance in the elderly ( $>60$ years old) $(59.0 \%)$. The access to hypertension drug therapy is greater in the
South and lower in the Midwest and Northeast regions; $56 \%$ of these therapies were provided by the Brazilian Unified Health System (SUS), 16\% by the Popular Pharmacy Program (Programa Farmácia Popular), and $2.3 \%$ by other sources.

Although the management of systemic arterial hypertension (SAH) is easily achieved in primary health care, hypertension control rates are still low (18.0-19.6\%). ${ }^{2}$ Poor treatment adherence has been considered the main cause of increased morbidity and mortality from

Mailing Address: Brigitte Martins dos Santos

Rua Santo Antônio, 50. Postal Code: 09550-051, São Caetano do Sul, SP - Brazil.

E-mail: brigitterie@yahoo.com.br 
cardiovascular diseases, reduced quality of life, increased medical costs, and increased demand for medical services. $^{3-5}$ These facts not only highlight the importance of the early detection of SAH, but also create an opportunity for the implementation of a pharmacotherapeutic follow-up program. The pharmacist contributes to the improvement of therapy adherence, and consequently, of the quality of life of hypertensive patients. This is of particular importance in regions like the North of Brazil, as the pharmacist provides an individual assessment of patients, based on their culture, experience with the therapy, and autonomy, to develop a "care plan" for the rational use of medications that can be shared by patients and professionals. ${ }^{6}$

In the northern region of Brazil, the adherence rate to drug therapy for chronic diseases is of $22.7 \%$, lower than the rates in the southern $(26.8 \%)$ and northern (29.2\%) regions. ${ }^{7}$ Thus, the present study was based on the assumption that adherence to drug treatment by hypertensive patients is low in the Brazilian north, leading to a high number of individuals with uncontrolled hypertension. In addition, pharmacotherapy follow-up in the primary care seems to improve the outcomes of this condition, unless issues like the correct use of medications and cultural diversity are addressed. Thus, we aimed to assess blood pressure control in hypertensive patients attending primary care clinics after the implementation of the pharmacotherapeutic follow-up program in a city in the north of Brazil.

\section{Methods}

\section{Study design and sample}

This was a descriptive, cross sectional, observational study conducted in three primary health care centers, one located on the riverbank and two in urban areas of the city of Santarem, in the west of Pará State, Brazil, between 2015 and 2017. The sample was selected by convenience. A total of 163 patients older than 18 years of age were included. These patients were registered in the National Program of Hypertension and Diabetes (Hiperpedia, Programa Nacional de Hipertensão e Diabetes Mellitus), had hypertension for more than six months, attended primary health care centers health and signed the informed consent form. Patients with secondary hypertension confirmed from medical records and those who had purchased at least one antihypertensive drug in the thirty days prior to the interview were excluded. This exclusion criterion was used to remove the influence of medication costs, which is considered one of the main predictors of nonadherence. For analysis of hypertension, we used the 2020 Brazilian Guidelines on Hypertension, which defines hypertension as systolic blood pressure (SBP) $\geq 140 \mathrm{mmHg}$ and diastolic blood pressure (DBP) $\geq 90 \mathrm{mmHg}{ }^{8}$

\section{Sociodemographic variables and outcome measures}

A semi-structured questionnaire was administered during the Hiperpedia follow-up visit for data collection. To determine the sociodemographic profile of patients, age, sex, educational attainment, and family income were collected; race/skin color was defined based on selfidentification or self-classification, ${ }^{9}$ and the classification was made according to The Brazilian Institute of Geography and Statistics (IBGE), namely, white, black, pardo, yellow and indigenous. In this study, "black race" was determined by the sum of black and pardo, as race is considered a social construct. ${ }^{10}$ In addition, patients were also questioned regarding the use of medicinal plants.

There is no gold standard for assessment of treatment adherence, and hence the researcher should choose the most appropriate method. ${ }^{11}$ In our study, we used the Morisky Medication Adherence Scale (MMAS-8), ${ }^{12,13}$ which has been translated and validated in Portuguese for use in hypertensive patients. The MMAS- 8 is composed of eight dichotomous questions ('yes' or 'no' answers), to prevent biased positive answers to questions made by health professionals, by inversion of answers related to an adherent behavior. Seven questions should be answered negatively, and only one, positively. The last question contains a five-option scale: "never", "almost never", "sometimes", "frequently", "always". The level of therapeutic adherence was determined by the sum of all correct answers and defined as: high adherence (eight points), moderate adherence (6-8 points), and low adherence (<6 points). The binary classification was used for data presentation, i.e., adherent (MMAS- $8=8$ points) versus non-adherent (MMAS- $8<8$ points).

Subsequently, patients were allocated into four groups: a) controlled/adherent; b) controlled/nonadherent; c) uncontrolled/adherent; and d) uncontrolled/ non-adherent.

Patients classified as "uncontrolled/nonadherent" $(n=63)$ were invited to participate in the pharmacotherapeutic follow-up program, according to the Dader method. ${ }^{14}$ The group was formed by 11 participants living in riverside areas and 52 patients living in urban areas. 
The pharmacotherapeutic follow-up program was developed in four steps, as illustrated in Figure 1.

In phase 3, the pharmaceutical interventions were conducted according to the Brazilian Ministry of Health standards for pharmaceutical consulting classified by the type of intervention: information and counseling; change or suggestion for change in therapy; monitoring; referral; and material provision. ${ }^{15}$ Therefore, actions were grounded mainly on education in health, conversation, and knowledge exchange, combining scientific and popular knowledge. In this stage, the first step was to establish a bond with the patient, by listening to his/her experience regarding drug therapy and clinical condition, since each individual has his/her own perceptions and behaviors about the therapy, based on culture, experiences, and knowledge about health and illness. ${ }^{16}$

\section{Statistical analysis}

Data were organized in an Excel spreadsheet (Microsoft Office 2013) and analyzed using the IBM SPSS Statistics
(Statistical Package for the Social Sciences) software, version 25.0 by descriptive statistics. Categorical variables were described as absolute and relative frequencies. All continuous variables had a non-normal distribution as tested by the Kolmogorov-Smirnov test and confirmed by the Shapiro-Wilk test. The likelihood-ratio test was used for categorical variables, as it produces more accurate results than the chi-square test in summary tables larger than $2 \times 2$. The McNemar test was used to detect differences before and after the pharmacotherapeutic follow-up. Statistical significance was set at $\mathrm{p}<0.05$ or $5 \%$.

\section{Ethical aspects}

The study was approved by the research ethics committee of the São Caetano do Sul University (CAAE 45931815.7.0000.5510; approval number 1.130.972,06/29/2015).

\section{Results}

Of the 163 hypertensive patients included in the study, 154 (94.5\%) were non-adherent to treatment

\begin{tabular}{l}
$\begin{array}{l}\text { Invitation to the study, presentation of the study objectives and methods, } \\
\text { obtaining of informed consent } \\
\text { Administration of questionnaires } \\
\text { Blood pressure measurements }\end{array}$ \\
$\begin{array}{l}\text { Phase } 1 \\
\text { Assessment of medications used by the patient } \\
\text { Blood pressure measurements } \\
\text { General instructions }\end{array}$ \\
Phase 2 \\
$\begin{array}{l}\text { Domiciliary visits: pharmaceutical intervention } \\
\text { Blood pressure measurements }\end{array}$ \\
\hline $\begin{array}{l}\text { Pomiciliary visits } \\
\text { Follow-up and evaluation }\end{array}$ \\
\hline
\end{tabular}


and $126(77.2 \%)$ had uncontrolled hypertension. Most patients were women $(73.0 \%)$, aged from 40 to 79 years $(82.9 \%)$, and of black race $(74.8 \%)$. Regarding educational attainment, $20.2 \%$ had no schooling, and $57.1 \%$ had elementary school; $35.6 \%$ earned less than one minimum wage, and $58.9 \%$ used medicinal plants. No statistically significant differences were found in sociodemographic characteristics and treatment adherence between patients with controlled and uncontrolled blood pressure (Table 1).

Of the 63 patients who accepted to participate in the "pharmacotherapy follow-up group" patients attending urban health care centers $(n=52)$ were those who most benefited from the program, with significant increase in the number of patients with controlled hypertension $(\mathrm{p}<0.001)$, and significant reduction in systolic and diastolic blood pressure $(\mathrm{p}<0.001)$. This was not observed among participants from the riverbank community $(\mathrm{n}=11)(\mathrm{p}>0.05)$ (Tables 2 and 3). In addition, a significant improvement in blood pressure levels, especially systolic blood pressure $(p<0.001)$, was seen in participants from both urban and riverside health center centers (Table 4).

\section{Discussion}

Before the pharmacotherapeutic follow-up program, the number of patients with uncontrolled hypertension was $77.2 \%$, with no significant differences between patients attending urban and riverside medical centers. A cross-sectional study conducted in Porto Velho, a city located in the Amazon area, showed a prevalence of $53.1 \%$ of hypertensive patients aged between 35 and 80 years. ${ }^{17}$ In riverbank communities of Madeira river (western Amazon), 26\% (95\% CI; 23-29\%) of adults had hypertension, $29 \%$ of men (95\% CI: $24-33 \%$ ) and $23 \%$ of women (95\%CI: 19-27\%). ${ }^{18}$

In addition, $94.5 \%$ of participants were non-adherent to treatment. Based on the literature, adherence to treatment in the north region of Brazil is only $22.7 \%$, compared with $38.1 \%$ and $31.6 \%$ in the northeast and middle west regions, respectively, and $26.8 \%$ and $29.2 \%$ in the in the South and Southeast, respectively. ${ }^{7}$ In a study conducted with data from the PNAUM, ${ }^{1}$ the prevalence of non-adherence to drug therapy in the North was $24.2 \%$, which was higher than in the south (17.0\%) and southeast (17.5\%) regions. ${ }^{19}$

According to Barreto et al., ${ }^{20}$ intervention measures aimed at improving blood pressure control are needed. Also, the authors support that hypertensive patients should be counseled regarding anti-hypertensive treatment, according to the Brazilian Ministry of Health protocol, requiring a multiprofessional teamwork in this regard. The presence of a pharmacist in multiprofessional teams is warranted to redefine healthcare models for chronic diseases, especially in primary care, to obtain better therapeutic results. ${ }^{21}$

Uncontrolled blood pressure has been frequently associated with low treatment adherence. ${ }^{3,22}$ Araújo \& Aras Junior ${ }^{23}$ reported that most of their studied patients had uncontrolled hypertension, regardless of treatment adherence. However, the authors observed an expected trend: patients with controlled hypertension had good treatment adherence, and most of patients with uncontrolled hypertension had poor adherence. Also according to the authors, adherence to anti-hypertensive therapy may be improved by patient education regarding the correct use of medication, making sure the patient understands it, and establishing strategies with family members to help the patient remember to take medication help.

In the present study, patients with uncontrolled hypertension but adherent to the therapy were referred to their physicians for assessment of their drug therapy and need for adjustments. One case food-drug interaction was detected in a patient adherent to drug therapy. The patient was instructed about the correct use of medication, and blood pressure levels were normalized after that. However, according to Araújo \& Aras Junior, ${ }^{23}$ although the Morisky-Green test is the most used method to quantify adherence to anti-hypertensive treatment in Brazil, enabling comparison between studies, the instrument may not be the most appropriate considering its low sensitivity (43.6\%).

Our results also showed that men were more adherent to treatment than women $(p=0.006)$. This contrasts with the literature that indicates a greater concern about health among women, who tend to seek more medical care and have a better blood pressure control than men, ${ }^{24,25}$ probably due to some cultural association that still needs to be elucidated. Besides, no statistically significant association was found between non-adherence to drug therapy and age $(\mathrm{p}=0.683)$. In the elderly, greater adherence to drug therapy is associated with more advanced age, as aging is associated with a higher prevalence of chronic degenerative diseases, which may make the patient more aware of his/her health condition and increase treatment adherence. ${ }^{26}$ 
Table 1 - Distribution of participants by sociodemographic characteristics and blood pressure control $(n=163)$, Santarem, Pará State, Brazil, 2017

\begin{tabular}{|c|c|c|c|c|c|c|c|}
\hline \multirow{2}{*}{ Variables } & \multicolumn{2}{|c|}{ Controlled blood pressure } & \multicolumn{2}{|c|}{ Uncontrolled blood pressure } & \multicolumn{2}{|c|}{ Total } & \multirow{2}{*}{ p-value } \\
\hline & $\mathbf{n}$ & $(\%)$ & $\mathbf{n}$ & $(\%)$ & $\mathbf{n}$ & $(\%)$ & \\
\hline \multicolumn{8}{|l|}{ Health center } \\
\hline Riverside & 5 & $(3.1)$ & 26 & $(15.9)$ & 31 & $(19.0)$ & \multirow{2}{*}{0.332} \\
\hline Urban & 32 & $(19.6)$ & 100 & $(61.3)$ & 132 & $(81.0)$ & \\
\hline \multicolumn{8}{|l|}{ Sex } \\
\hline Female & 26 & $(16.0)$ & 93 & $(57.1)$ & 119 & $(73.0)$ & \multirow{2}{*}{0.672} \\
\hline Male & 11 & (6.7) & 33 & $(20.2)$ & 44 & $(27.0)$ & \\
\hline \multicolumn{8}{|l|}{ Age (years) } \\
\hline $20-39$ & 5 & $(3.1)$ & 7 & $(4.3)$ & 12 & $(7.4)$ & \multirow{4}{*}{0.314} \\
\hline $40-59$ & 16 & $(9.8)$ & 53 & $(32.5)$ & 69 & $(42.3)$ & \\
\hline $60-79$ & 14 & (8.6) & 54 & $(33.1)$ & 68 & $(41.7)$ & \\
\hline$\geq 80$ & 2 & $(1.2)$ & 12 & $(7.4)$ & 14 & $(8.6)$ & \\
\hline \multicolumn{8}{|l|}{ Race/Skin color } \\
\hline White & 3 & $(1.8)$ & 16 & $(9.8)$ & 19 & $(11.6)$ & \multirow{5}{*}{0.398} \\
\hline Black & 28 & $(17.1)$ & 94 & $(57.7)$ & 122 & $(74.8)$ & \\
\hline Yellow & - & - & 2 & $(1.2)$ & 2 & $(1.2)$ & \\
\hline Indigenous & - & - & 3 & $(1.8)$ & 3 & $(1.8)$ & \\
\hline Non-responders & 6 & $(3.7)$ & 11 & (6.7) & 17 & $(10.4)$ & \\
\hline
\end{tabular}

Educational attainment

\begin{tabular}{|c|c|c|c|c|c|c|c|}
\hline Elementary school & 20 & $(12.2)$ & 73 & $(44.8)$ & 93 & $(57.1)$ & \multirow{4}{*}{0.847} \\
\hline Secondary school & 8 & $(4.9)$ & 25 & $(15.3)$ & 33 & $(20.2)$ & \\
\hline None & 9 & $(5.5)$ & 24 & $(14.7)$ & 33 & $(20.2)$ & \\
\hline Non-responders & - & - & 4 & $(2.4)$ & 4 & $(2.4)$ & \\
\hline \multicolumn{8}{|l|}{ Income } \\
\hline$<1 \mathrm{MW}$ & 14 & (8.6) & 44 & $(27.0)$ & 58 & $(35.6)$ & \multirow{5}{*}{0.870} \\
\hline $1 \mathrm{a}<2 \mathrm{WM}$ & 18 & $(11.0)$ & 64 & $(39.3)$ & 82 & $(50.3)$ & \\
\hline $2 \mathrm{a}<3 \mathrm{MW}$ & 2 & $(1.2)$ & 10 & $(6.1)$ & 12 & $(7.4)$ & \\
\hline 3 a 4 MW & 2 & $(1.2)$ & 2 & $(1.2)$ & 4 & $(2.4)$ & \\
\hline Non-responders & 1 & $(0.6)$ & 6 & $(3.7)$ & 7 & $(4.3)$ & \\
\hline \multicolumn{8}{|l|}{ Use of medicinal plants } \\
\hline Yes & 19 & (11.6) & 77 & $(47.2)$ & 96 & $(58.9)$ & \multirow{3}{*}{0.385} \\
\hline No & 12 & $(7.4)$ & 38 & $(23.3)$ & 50 & $(30.7)$ & \\
\hline Non-responders & 6 & (3.7) & 11 & (6.7) & 17 & $(10.4)$ & \\
\hline \multicolumn{8}{|l|}{ Treatment adherence } \\
\hline Adherent & 4 & $(2.4)$ & 5 & (3.1) & 9 & $(5.5)$ & \multirow{2}{*}{0.137} \\
\hline Non-adherent & 33 & $(20.2)$ & 121 & $(74.2)$ & 154 & $(94.5)$ & \\
\hline
\end{tabular}




\begin{tabular}{|c|c|c|c|c|c|c|c|c|c|c|}
\hline \multirow{3}{*}{ Variables } & \multicolumn{5}{|c|}{ Riverside $(\mathrm{n}=11)$} & \multicolumn{5}{|c|}{ Urban area $(n=52)$} \\
\hline & \multicolumn{2}{|c|}{ Before } & \multicolumn{2}{|c|}{ After } & \multirow{2}{*}{ p-value* } & \multicolumn{2}{|c|}{ Before } & \multicolumn{2}{|c|}{ After } & \multirow{2}{*}{ p-value* } \\
\hline & $\mathbf{n}$ & $(\%)$ & $\mathbf{n}$ & $(\%)$ & & $\mathbf{n}$ & $(\%)$ & $\mathbf{n}$ & (\%) & \\
\hline \multicolumn{11}{|l|}{ Blood pressure } \\
\hline Controlled & - & - & 3 & $(27.3)$ & 0.250 & - & - & 17 & $(34.0)$ & \multirow{2}{*}{$<0.001$} \\
\hline Uncontrolled & 11 & $(100)$ & 8 & $(72.7)$ & & 52 & $(100)$ & 35 & $(66.0)$ & \\
\hline
\end{tabular}

Table 3 - Systolic and diastolic blood pressure of patients attending health centers in urban and riverside areas before and after the pharmacological follow-up program, Santarem, Pará State, Brazil, 2017

\begin{tabular}{|c|c|c|c|c|c|c|}
\hline Variable & & & Median & 25 th percentile & 75th percentile & p-value ${ }^{*}$ \\
\hline \multirow{4}{*}{$\begin{array}{l}\text { Riverside } \\
\mathrm{n}=11\end{array}$} & \multirow{2}{*}{ SBP } & Before & 160.0 & 148.0 & 170.0 & \multirow{2}{*}{0.110} \\
\hline & & After & 140.0 & 130.0 & 160.0 & \\
\hline & \multirow{2}{*}{ DBP } & Before & 80.0 & 78.0 & 90.0 & \multirow{2}{*}{0.131} \\
\hline & & After & 80.0 & 80.0 & 90.0 & \\
\hline \multirow{4}{*}{$\begin{array}{l}\text { Urban } \\
\mathrm{n}=52\end{array}$} & \multirow{2}{*}{ SBP } & Before & 153.0 & 142.5 & 169.5 & \multirow{2}{*}{$<0.001$} \\
\hline & & After & 140.0 & 130.0 & 143.0 & \\
\hline & \multirow{2}{*}{ DBP } & Before & 92.0 & 86.5 & 100.0 & \multirow{2}{*}{$<0.001$} \\
\hline & & After & 85.0 & 80.0 & 90.0 & \\
\hline
\end{tabular}

Although the relationship between socioeconomical factors, like income and educational attainment, and adherence to treatment has been well established, 7,21,27 we did not observe a statistically significant correlation between adherence and educational level ( $p=0.589)$. Low levels of educational attainment and income had a negative impact on drug treatment adherence. Indeed, users of the public health system in Brazil, with low socioeconomic status, may not be able to purchase medications covered by the public system, in case of lack of them. ${ }^{28}$

In contrast with the literature, we did not find statistically significant differences in adherence or race between adherent and non-adherent patients $(\mathrm{p}=0.075)$. Most participants self-identified as Black, which may be explained by the high concentration of African descendants and indigenous in the west of Pará State, where the study was conducted. According to the literature, Black individuals have higher blood pressure levels and lower blood pressure control, which may be due to low socioeconomic status, complexity of drug therapy and presence of comorbidities. ${ }^{29}$

One aspect that may interfere with the therapy is the lack of medications in the public health care sector, especially when cities and states do not receive the minimum financial resources, in contrast to what is predicted by the law number $8080 / 90^{30}$ and ordinances 204/200731 and 1.555/13. ${ }^{32}$ Vaz et al., ${ }^{33}$ who evaluated the participation of the central, state and municipal governments in the funding of the basic components of 


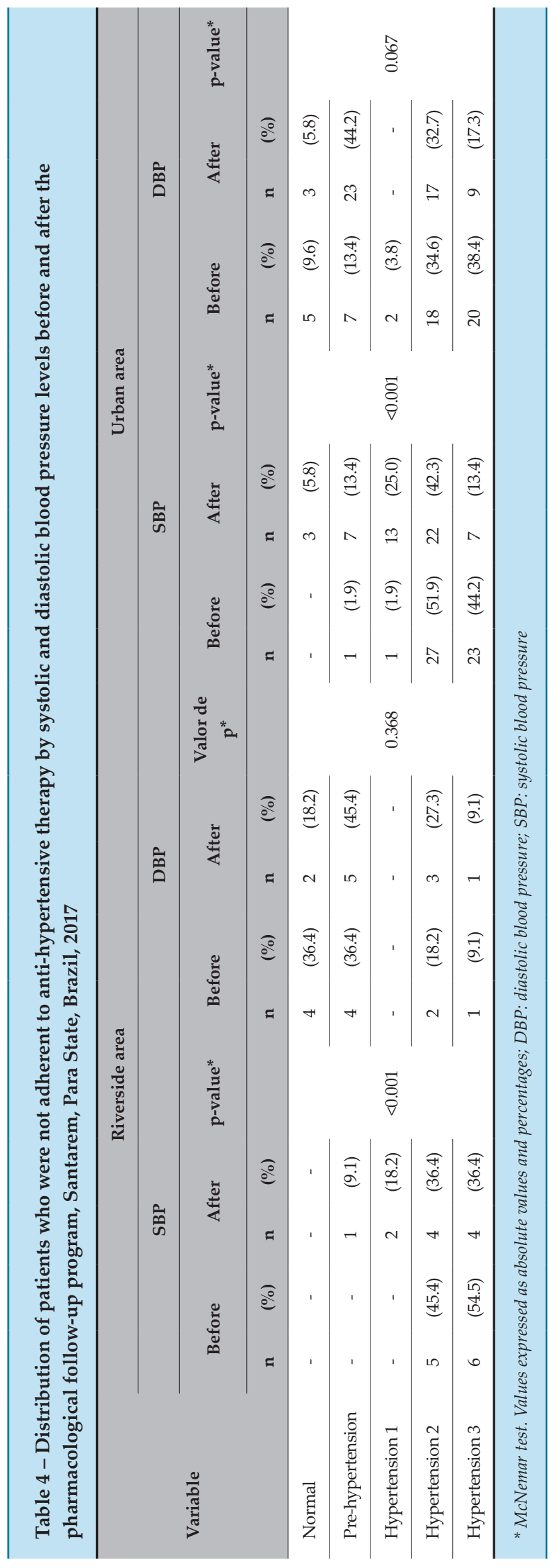

pharmaceutical assistance in the city of Santarem, Pará, between 2010 and 2015, found that the minimum per capita expenditure value, legally established, was not achieved. The study by Mendes et al., ${ }^{34}$ revealed a low availability of medications to all population strata. ${ }^{34}$ Tavares et al., ${ }^{7}$ reported that a low adherence to the drugs prescribed for the treatment of chronic diseases was more frequent among patients who had to pay for part of their medications than among those who obtained the medications for free.

In addition, our results showed that the pharmaceutical follow-up program improved blood pressure control, with reduction of systolic and diastolic blood pressure levels, particularly in participants living in urban areas than in riverbank areas. This may be due to the greater access to health care by urban populations, which requires further studies to be confirmed. Also, a study performed in Porto Velho showed higher rates of hypertension in urban than riverbank areas ( $55.48 \%$ vs. $48.87 \%$ [ $p=0.02$ ] and $61.25 \%$ vs. $52.30 \%$ [p $<0.01]$, respectively). ${ }^{18}$

Regarding the stage of the pharmacotherapeutic follow-up program, we identified some drug-related problems, including patients with health problems and uncontrolled blood pressure due to a non-quantitative ineffectiveness of the medication.

Limitations of the study include the assessment of treatment adherence by self-reporting and the observational nature of the study, which prevents causal inferences.

\section{Conclusions}

The present study showed a low adherence to drug therapy and uncontrolled hypertension among users of the Hiperpedia. It also pointed out the need for referral of adherent and non-adherent patients with uncontrolled hypertension to their general practitioner. This finding justifies the importance of an individualized treatment through a pharmacotherapeutic follow-up in the primary care setting, which may improve the outcomes of chronic diseases, such as systemic arterial hypertension, mainly when regional and cultural specificities are respected.

The pharmacist plays an important role in the healthcare team. This role becomes even more vital in the north of the country, considering its territorial and cultural diversity, as well as poor access to health services and even to drug treatment. The pharmacist needs to 
develop and provide individualized care, considering all particularities of this geographic region.

Finally, further studies may elucidate the causes of differences in treatment adherence in the city of Santarem, and in hypertension control rates between urban and riverside communities in the north region of Brazil.

\section{Potential Conflict of Interest}

No potential conflict of interest relevant to this article was reported.

\section{Sources of Funding}

There were no external funding sources for this study.

\section{Study Association}

This study is not associated with any thesis or dissertation work.

\section{References}

1. Brasil. Ministério da Saúde. Secretaria de Ciência, Tecnologia e Insumos Estratégicos. Componente populacional: resultados. Brasília; 2016.

2. Brasil. Ministério da Saúde. Cadernos de Atenção Básica: Estratégias para o cuidado da pessoa com doença crônica - Hipertensão Arterial Sistêmica. Brasília;2010.

3. Freitas JGA, Nielson SEO, Porto CC. Adesão ao tratamento farmacológico em idosos hipertensos: uma revisão integrativa da literatura. Rev Soc. Bras Clín Méd. 2015;13(1):75-84. Disponível em: http://files.bvs.br/upload/S/1679-1010/2015/v13n1/a4782.pdf.

4. World Health Organization.(WHO). Adherence to long-term therapies: evidence for action. Geneva ; 2003.

5. Luz FE, Santos BRM, Sabino W. Estudo comparativo de mortalidade por doenças cardiovasculares em São Caetano do Sul (SP), Brasil, no período de 1980 a 2010. Ciên Saúde Colet. 2017;22(1):161-8. doi 10.1590/1413-81232017221.18362015.

6. Campese M, Soares L, Leite SN, Farias MR. O dever da profissão farmacêutica e a clínica farmacêutica. In Atuação clínica e organização, de Luís Soares, et al. Florianópolis: UFSC; 2016. p.21-43. (Assistência Farmacológica no Brasil, Política e Gestão Clínica, v.5)

7. Tavares NUL, Bertoldi AD, Mengue SS, Arrais PSD, Luiza VL, Oliveira MA, et al. Factors associated with low adherence to medicine treatment for chronic diseases in Brazil. Rev Saúde Pública.2016;50(Suppl 2):10s. doi 10.1590/s1518-8787.2016050006150.

8. Sociedade Brasileira de Cardiologia, Sociedade Brasileira de Hipertensão, Sociedade Brasileira de Nefrologia. Diretrizes Brasileiras de Hipertensão Arterial - 2020. Arq Bras Cardiol. 2021;116(3): 516-658. doi 10.36660/abc.20201238.

9. Berquó E. I Curso de Metodologia e Pesquisa em Saúde da População Negra. Campinas: Unicamp; 2008.

10. Guimarães ASA. Como trabalhar com "raça" em sociologia. Educação e Pesquisa. 2003;29(1):93-107. Disponível em: https://www.scielo.br/ pdf/ep/v29n1/a08v29n1.pdf.

\section{Ethics approval and consent to participate}

This study was approved by the Ethics Committee of the Universidade Municipal de São Caetano do Sul under the protocol number 1.130.972. All the procedures in this study were in accordance with the 1975 Helsinki Declaration, updated in 2013. Informed consent was obtained from all participants included in the study.

\section{Author contributions}

Conception and design of the research: Sabino W. Acquisition of data: Sabino W, Gomes IS, Rossi EM. Analysis and interpretation of the data: Sabino W, Gomes IS, Rossi EM, Mendes SJ, Santos BRM. Statistical analysis: Sabino W. Writing of the manuscript: Sabino W, Gomes IS, Rossi EM, Mendes SJ, Santos BRM. Critical revision of the manuscript for intellectual content: Sabino W.

11. Pareja-Martínez E, Esquivel-Prados E, Martínez-Martínez F, GarciaCorpas, JP. Questionnaires on adherence to antihypertensive treatment: a systematic review of published questionnaires and their psychometric properties. Int J Clin Pharm. 2020;42(2):355-65. doi: 10.1007/s11096-020-00981-x.

12. Oliveira-Filho AD. Relação entre a escala de adesão terapêutica de oito itens de Morisky (MMAS-8) e o controle da pressão arterial. Arq Bras Cardiol. 2012;99(1):649-58. doi: 10.1590/S0066-782X2012005000053.

13. Oliveira-Filho AD, Morisky DE, Neves SJF, Costa FA, de Lyra DF. The 8-item Morisky medication adherence scale validation of a Brazilian-Portuguese version in hypertensive adults. Research Social and Administration Pharmaceutical. (RSAP). 2014;10(3):554-61. doi: 10.1016/j.sapharm.2013.10.006.

14. Hernandéz DS, Castro MMS, Dáder MJ. Método Dáder. Guía de seguimiento farmacoterapéutico. 3.ed. Granada (Espanha): Universidad de Granada; 2007. 128p. Disponível em: https://www. ugr.es/ cts131/esp/guias/GUIA\%20FINAL\%20DADER.pdf.

15. Angonesi D, Sevalho G. Atenção farmacêutica: fundamentação conceitual e crítica para um modelo brasileiro. Ciên Saúde Colet. 2010;15(supl 3):3603-14. doi 10.1590/S1413-81232010000900035.

16. Brasil. Secretaria de Ciência, Tecnologia e Insumos Estratégicos. Departamento de Assistência Farmacêutica e Insumos Estratégicos. Capacitação para implantação dos serviços de clínica farmacêutica. Brasília; 2014. (Cuidado Farmacêutico na Atenção Básica, Caderno 2)

17. Almeida RCA, Dias DJL, Deguchi KTP, Spesia CH, Coelho OR. Prevalence and treatment of hypertension in urban and riverside areas in Porto Velho, the Brazilian Amazon. Postgrad Med. 2015;127(1):66-72. doi 10.1080/00325481.2015.993574.

18. Oliveira BFA, Mourão DS, Gomes N, Costa JMC, Souza AV, Bastos WR, et al. Prevalência de hipertensão arterial em comunidades ribeirinhas do Rio Madeira, Amazônia Ocidental Brasileira. Cad Saúde Pública.2013;29(8):1617-30. doi 10.1590/0102-311X00146212.

19. Drummond ED, Simões TC, Andrade FB. Avaliação da não adesão à farmacoterapia de doenças crônicas e desigualdades socioeconômicas 
no Brasil. Rev bras epidemiol. 2020;23:E200080. [Internet] [cited 2021 May 17]; Disponível em http://www.scielo.br/scielo.php?script=sci_ arttext\&pid=S1415-790X2020000100470\&lng=en. doi:10.1590/1980549720200080

20. Barreto MS, Matsuda LM, Marcon SS. Fatores associados ao inadequado controle pressórico em pacientes da atenção primária. Escola de Enfermagem Anna Nery. 2016;20(1):114-20. doi $10.5935 / 1414-8145.20160016$.

21. Mendes EV. As redes de atenção à saúde. Ciên Saúde Coletiva. 2010;15(5): 2297-305. doi 10.1590/S1413-81232010000500005.

22. Chor D, Ribeiro ALP, Carvalho MS, Duncan BB, Lotufo PA, Nobre AA, et al. Prevalence, awareness, treatment and influence of socioeconomic variables on control of high blood pressure: results of the ELSA-Brasil study. PLoS One. 2015;10(6): e0127382. doi 10.1371/ journal.pone.0127382. eCollection 2015.

23. Araújo LBS, Aras Junior R. Association between therapeutic adherence and the profile of patients with resistant hypertension. Int J Cardiovasc Sci. 2020;33(2):121-30. doi: 10.5935/2359-4802.20190077.

24. Barbosa J, Silva AA, Santos A, Monteiro Júnior F, Barbosa M, Barbosa $\mathrm{M}$, et al. Prevalência da hipertensão arterial em adultos e fatores associados em São Luís - MA. Arq Bras Cardiol. 2008;91(4):260-6. doi 10.1590/S0066-782X2008001600009.

25. Mendes TAB, Goldbaum M, Segri NJ, Barros MBA, César CLG, Carandina L. Factors associated with the prevalence of hypertension and control practices among elderly residents of São Paulo city, Brazil. Cad Saúde Pública. 2013;29(11):2275-86. doi 10.1590/0102311x00151312.

26. Mengue SS, Bertoldi AD, Ramos LR, Farias MR, Oliveira MA, Tavares NUL, et al. Access to and use of high blood pressure medications in Brazil. Rev Saúde Pública. 2016;50(Suppl. 2):6s. doi: 10.1590/s15188787.2016050006154.

27. Girotto E, Andrade SM, Cabrera MAS, Matsuo T. Adesão ao tratamento farmacológico e não farmacológico e fatores associados na atenção primária da hipertensão arterial. Ciên Saúde Coletiva.2013;18(6):1763-72. doi 10.1590/S1413-81232013000600027.

28. Tavares NUL, Bertoldi AD, Thumé E, Facchini LA, França GVA, Mengue SS. Fatores associados à baixa adesão ao tratamento em idosos. Rev Saúde Pública. 2013;47(6):1-9. doi 10.1590/S00348910.2013047004834.

29. Lessa Í, Magalhães L, Araújo MJ, Almeida Filho N, Aquino E, Oliveira MMC. Hipertensão arterial na população adulta de Salvador (BA) - Brasil. Arq Bras Cardiol. 2006;87(6):747-56. doi 10.1590/S0066782X2006001900011.

30. Brasil. Lei no 8.080 , de 19 de setembro de 1990. Dispõe sobre as condições para promoção, proteção e recuperação da saúde, a organização e o funcionamento dos serviços correspondentes e dá outras providências. Diário Oficial da União, Brasília (DF), 1990 set 20: 18055 .

31. Brasil. Portaria no 204, de 29 de janeiro de 2007. Regulamenta o financiamento e a transferência dos recursos federais para as ações e os serviços de saúde, na forma de blocos de financiamento, com o respectivo monitoramento e controle. Diário Oficial da União, Brasília (DF), 2007 jan 31; Seção 1: 45.

32. Brasil. Portaria no 1.555 , de 30 de julho de 2013. Dispõe sobre as normas de financiamento e de execução do componente básico da assistência f'armacêutica no âmbito do Sistema Único de Saúde (SUS). Diário Oficial da União, Brasília (DF), 2013 jul 31; Seção 1: 71.

33. Vaz MM, Martins dos Santos BR, Sabino W. O financiamento do componente básico da assistência farmacêutica no município de Santarém, Pará: uma análise comparativa. Atenção Primária a Saúde (APS).2010;1(3):162-72. doi 10.14295/aps.v1i3.38.

34. Mendes LV, Campos MR, Chaves GC, Silva RM, Freitas OS, Costa $\mathrm{KS}$, et al. Disponibilidade de medicamentos nas unidades básicas de saúde e fatores relacionados: uma abordagem transversal. Saúde Debate. 2014; 38(especial):108-23. doi: 10.5935/0103-1104.2014S009. 